\title{
Teaching and Learning ICT as a Subject in Nigerian Secondary Schools: The Challenge of Pre-service Teachers Education Preparation
}

\author{
Olusegun Ojo Bakare \\ Institute of Education, Faculty of Education Obafemi Awolowo University, Ile-Ife, Nigeria
}

\begin{abstract}
This study investigates the factors militating against the preparation of pre-service teachers' training for the teaching of computer science education (CSE) in Nigerian secondary schools. The study consisted of 165 pre-service teachers and 11 teacher educators from Osun State Colleges of Education. The study employed quantitative research design using survey research design to elicit data from the respondents. The results of the study reveal that the computer science educators teaching the pre-service teachers were qualified but inadequate in terms of number; computer facilities were inadequate and the available ones are obsolete; lecture method was mostly used for the training of the pre-service teachers; and the pre-service teachers have low proficiency in both hardware and software components. The study concluded that the CSE pre-service teachers in Osun State Colleges of Education were not proficient in computer software and hardware component because they had low level of computer software and hardware component proficiency. The implication and recommendations were drawn from the study that can help educational stakeholders as well as Nigerian education policy makers.
\end{abstract}

\section{Introduction}

The challenges confronting the preparation of pre-service teacher education are enormous at both national and international levels. These setbacks ranging from lack of ICT infrastructure, teachers' ICT competency, comprehensive ICT policy and its awareness among educators, lack of teachers' ICT pedagogical development as well as lack of teachers' computer efficacy [1], [7].

These challenges have the tendency to incapacitate Nigerian teachers either by not using ICT as a tool to deliver curriculum or taught effectively as a subject in classrooms. It is therefore important to know how computer teachers to be are being prepared to teach ICT in Nigerian secondary schools. It is on this basis that this study is set out to examine the challenges confronting preparation of pre-service teachers studying computer science education in Nigeria Colleges of Education using Osun State Colleges of Education as case study.

The study is to determine quality and adequacy of staff assigned to train the pre-service teachers as well as facilities available in Nigerian teachers' education; examine the strategies employed in training the pre-service teachers; and investigates pre-service teachers' proficiency in specific Computer Education components involving software and hardware. Four research questions emanated from these objectives, namely:

RQ1. Are there qualified and adequate CSE lectures in the Colleges of Education?

RQ2. Are the computer facilities in computer laboratories for the pre-service computer teachers in the Colleges of Education adequate and has the quality required?

RQ3. What are the training strategies for the CSE pre-service teachers?

RQ4. How proficient are the pre-service teachers in computer software and hardware utilization?

\section{Literature Review}

Studies [8], [9] have been conducted to examine different sources of challenge confronting teaching ICT as a subject in schools both locally and at international level. For example, Odogwu [8], found that there is inadequate teacher to teach ICT in schools in Nigeria. This inadequacy of ICT trained teachers in schools will hinder students having adequate knowledge of ICT at various schools. Similarly, Toscany-Academy [9] finding showed $87 \%$ unqualified computer lecturers in Nigerian schools teaching ICT. It can be deduced from the findings of Toscany-Academy [9] and Odogwu [8] that ICT literacy cannot be taught effectively where teachers lack adequate ICT knowledge even the basic skills. This is supported by findings of Nwangwu, Obi and Ogwu [5] that teacher lacks skill to teach learners ICT literacy.

According to NCCE [10] document, the minimum qualification of academic staff teaching at teachers' education in Nigeria must be a Bachelor degree in Computer Science with at least a Second Class Lower (2/2) (Honours) degree in Computer Science and a professional teaching qualification or a minimum of Bachelor of Education Degree in computer Science with at least Second Class Lower $(2 / 2)$ status. With this requirement, it is expected that pre-service teachers in Nigerian teacher education should have access to qualified educators. In the study of Chao [11], findings reveal that there are unqualified trainer training teachers. Mndzebele [12] found in Swaziland that the pre-service teachers were 
taught different courses in ICT but they were not linked to pedagogy. It should be noted that if teacher educators in Nigerian colleges of education will processed the right qualification, their products (graduates) should be able to teach ICT as a subject at secondary school as well use ICT to teach other science subjects effectively.

In addition, the NCCE document also specified that, there must be a minimum of eight (8) computer science education academic staff to teach in a College of Education before it could be accredited. It further stated that the staff-students ratio should be 1:25. Goshit [13] found inadequate ICT manpower in the schools as a barrier to ICT teaching in schools. similarly, Adomi and Kpangban [1] found lack of ICT teacher as a problem hindering teaching ICT as a subject in Nigerian schools.

ICT facilities deficiency is another challenge confronting the preparation of pre-service teachers for teaching ICT. For instance, Oyelekan [14] found inadequacy of ICT facilities as a problem in the two Colleges of Education in Plateau State. Similar finding of Yusuf [15] also shows, that in Africa, there is low access to basic ICT equipment, low internet connectivity, low participation in the development of ICT equipment, and even low involvement in software development. The available ICT facilities are obsolete [4]. This situation is still valid till date even after decades. The lack of these facilities hampers teacher's use of ICT in schools [16], [18]. However, Yang [19] argued that the use of ICT during learning practice would lead to competent and confident use of students, while lack of it would lead to their little use of ICT facilities for learning. The investigations carried out by Vanguard Learning showed, that many schools in Nigeria lack modern computer technology and that most available computers have lack electricity connectivity [20]. This underpinned the rationale for traditional method of teaching in most Nigerian secondary schools.

The NCCE document states that for Colleges to run a Computer Science Education programme, it must provide one computer for a group of not more than 2 students $(1: 2)$ as a minimum condition. In a study conducted by Warschauer [21] found that three students to use a computer in U.S. public schools as at 2008. In most developing nation like Nigeria this is far from reality.

Furthermore, Alade [22] submitted that there is an urgent need for a paradigm shift from conventional teaching to a practical demonstration. This was demonstrated in Bamidele [23] finding which reveals $65 \%$ of the students who used computers and had better result than the average students in the control class. Findings also shown that the effectiveness in the use of ICT to support learning is a determinant of curriculum content as well as the instructional strategy, such that, when appropriate content matches appropriate strategies, students and teachers will benefit immensely [24], [25]. This is truism because teachers targeted ICT training content is what, it is needed in Nigeria Colleges of Education to be effective [7], [26].

\section{Materials and Methods}

Survey research design was adopted for the study and data were collected using various instruments. These instruments seek information on the availability and adequacy of computer laboratory facilities in the Colleges, staff strengths and their qualifications, the strategies employed in training the pre-service teachers and students' proficiency in specific Computer Education components involving software and hardware. The study sample size comprises $168(40 \%)$ of the final year pre-service teachers and 11 academic staff of the two colleges of education. The sample was drawn using random sampling technique. The final year pre-service teachers were selected because they would have had all the training expected of them. All the academic staffs from CSE Department of the two institutions were considered because of their small size. Data was analysed using simple percentages.

\section{Results}

RQ1a: Are there qualified CSE lectures in the Colleges of Education?

To answer this research question, a departmental record was used to assess staff qualification in Computer Science Department from the two Colleges of Education in Osun State. The result was compared with the minimum qualification requirements of academic staff by NCCE. The result is as presented in Table 1.

From Table 1, $54.5 \%$ of the computer teacher educators in Osun State Colleges of Education met the minimum qualification requirements, $18.2 \%$ had degree in computer but had no teaching qualification, while $27.3 \%$ of them are not qualified at all. It can be concluded that $54.5 \%$ of the CSE academic staff were qualified because they met the minimum requirements set by NCCE to teach as a computer teacher educator at Nigeria Colleges of Education.

RQ1b: Are there adequate CSE lectures in the Colleges of Education?

To answer this research question, a Departmental record containing the list of staff was used to assess staff strength in each Computer Science Department at the two Colleges of Education in Osun State. The result was then compared with the minimum number of academic staff that must be employed to teach Computer Science Education courses at Nigeria Colleges of Education. The result is as presented in Table 2. 
Table 1. Qualification of Computer Teacher Educators in Osun State Colleges of Education

\begin{tabular}{|l|l|l|}
\hline Computer Lecturer Requirements & Number & Percentage \\
\hline Degree in Computer with Second Class Lower (2/2) only & 2 & $18.2 \%$ \\
\hline Degree in Computer with Second Class Lower (2/2) and Teaching Qualification & 6 & $54.5 \%$ \\
\hline Degree in none Computer Area & - & - \\
\hline HND with Teaching Qualification & - & - \\
\hline HND without Teaching Qualification & 3 & $27.3 \%$ \\
\hline
\end{tabular}

Table 2. Computer Science Lecturers in Osun State Colleges of Education

\begin{tabular}{|l|l|l|l|}
\hline College & Staff Size & Computer Students' Enrolment & Computer Staff Students' Ratio \\
\hline Osun State College of Education, Ilesa & $5(<8)$ & 302 & $1: 60.4$ \\
\hline Osun State College of Education, Ila & $6(<8)$ & 690 & $1: 115$ \\
\hline Total & 11 & 992 & $1: 90.18$ \\
\hline
\end{tabular}

From Table 2, there are 5 computer lecturers from Osun State College of Education Ilesa while 6 are in College of Education Ila. Therefore, the ratio of total number of available computer lecturers to the population of final year Comp1uter Science Education students is 11:420 (approximately 1:38.2). To compare the number of academic staff on ground that will teach Computer Science Education in each Colleges of Education in Osun State to the minimum number (8) computer lecturers expected in each Colleges of Education, it can be concluded that the computer lecturers in the two Colleges of Education in Osun State were not adequate.

RQ2a: Are the computer facilities in computer laboratories for the pre-service computer teachers in the Colleges of Education of the quality required?

This research question is divided into two aspects. The first part is to determine the quality of the computer facilities at the computer laboratories for computer pre-service teachers while the second aspect is to determine the adequacy of the computer facilities to answer the first aspect of the research question, a facility checklist consisting of minimum computer facility that a College of Education running computer programme must processed, was used. The inventories of all computer facilities in the Department of Computer Science Education in the Colleges were taken. The checklist rated computer facilities as: number available, number functional, and number not functional. The result is as presented in Table 3.

If quality of the facilities were rated such as between 0 and $39.4 \%$ to be 'Poor Quality', 39.5\% to $49.4 \%$ as 'Low Quality' and $49.5 \%$ and above as 'Good Quality'. Table 3 showed that, $43.2 \%$ of component of the computer facilities are functional, all computers are on local network, $31.8 \%$ of the available computers had INTEL PIV 3GHZ (100 FSB) MMX, DVD ROM Drive, Flat Screen Monitor, USB Keyboard and USB Mouse. 29.5\% of the computers had 120 GBHD. None of the computers had 2GB Ram. Also none of the computers were connected to the Internet. Scanner was not found in any of the laboratories for students and lecturers' use. No lecturer was presented a departmental laptop in any of the two Computer Science Education Departments. One projector and printer were found in each of the laboratories of the COE. It could be concluded that, the computer facilities that were on ground at the two Colleges of Education in Osun State for students' practical demonstration, did not meet the quality recommended by the NCCE for the computer science education programme.

RQ2b: Are the computer facilities in computer laboratories for the pre-service computer teachers in the Colleges of Education adequate?

Computer facilities checklist was used to extract the total number of functional computers for preservice computer teachers for practical demonstration. The result is as shown in Table 4.

According to information on Table 4 and 5, the ratio of available number of computers in the COE to the sample population of the study was 41:11 (approximately 4:1). This implies that, 4 students will be using one computer. However, the ratio of the functional computers to students is 168:19 (approximately 9:1). This translates to nine students on a functional computer.

From Table 1 and $4.3 \mathrm{e}$, the ratio of available number of computers in the Colleges to the population of computer science students was 23:1 (approximately 23:1). This translates to twenty three (23) students to use computer. While the ratio of functional computers in the two Colleges of Education to the population of computer science students in the Colleges is 52:1. That is 53 students to use one computer. It can therefore be concluded that the numbers of computers available for the use of the pre-service teachers' practical demonstration in software programming were not adequate. 
Table 3. Components of Computer Facilities in Osun State Colleges of Education

\begin{tabular}{|l|l|l|l|}
\hline s/n & Computer Facilities & Numbers Available & Numbers Functional \\
\hline 1 & Numbers of Computer & 44 & $19(43.2 \%)$ \\
\hline 2 & Numbers of computers with INTEL PIV 3GHZ (100 FSB) MMX & 14 & $14(31.8 \%)$ \\
\hline 3 & Numbers of computers with 2 GB RAM & 0 & 0 \\
\hline 4 & Numbers of computers with 120 GBHD & 14 & $13(29.5 \%)$ \\
\hline 5 & Numbers of computers with DVD ROM Drive & 14 & $14(31.8 \%)$ \\
\hline 6 & Numbers of computers with Flat Screen Monitor & 14 & $14(31.8 \%)$ \\
\hline 7 & Numbers of computers with USB Keyboard and & 14 & $14(31.8 \%)$ \\
\hline 8 & Numbers of computers with USB Mouse & 14 & $14(31.8 \%)$ \\
\hline 9 & Numbers of computers with SUBMIDI PIV casing & 44 & 44 \\
\hline 10 & Numbers of 650 VA UPS for each computer system & 44 & 44 \\
\hline 11 & Numbers of 1000-Watt stabilizers for each system & 44 & 44 \\
\hline 12 & Numbers of computers on Local Area Network & 44 & 44 \\
\hline 13 & Numbers of computers connected to the Internet & 0 & 0 \\
\hline 14 & Numbers of Scanners & 0 & 0 \\
\hline 15 & Numbers of Printer (Laser printers and Desk Jet Printers) & 2 & 2 \\
\hline 16 & Numbers of Computer projectors & 2 & 2 \\
\hline 17 & Laptop Computer to each lecturer of the department & 0 & 0 \\
\hline 18 & Local journals on computer studies education & - & - \\
\hline 19 & International journals on computer studies education & - & - \\
\hline
\end{tabular}

Table 4. Available Computer Facilities for Computer Student's Practical demonstration

\begin{tabular}{|l|l|l|}
\hline Facilities & $\begin{array}{l}\text { Number } \\
\text { Available }\end{array}$ & Number of Functional Facilities \\
\hline Computer & 44 & $19(43.2 \%)$ \\
\hline Scanner & 0 & 0 \\
\hline Projector & 2 & $2(100.0 \%)$ \\
\hline Printers & 3 & $3(100.0 \%)$ \\
\hline
\end{tabular}

Table 5. Computer Science Students in Osun State Colleges of Education

\begin{tabular}{|l|l|l|l|}
\hline College & Ilesa & Ila & Total \\
\hline Year One & 174 & 200 & 374 \\
\hline Year Two & 67 & 250 & 317 \\
\hline Year Three & 61 & 240 & 301 \\
\hline Total & 302 & 690 & 992 \\
\hline Ratio of Functional Computers & 15.89474 & 36.31579 & 52.21053 \\
\hline
\end{tabular}

RQ3: What are the strategies employed by the CSE lecturers for training the pre-service teachers?

To answer this research question, a Computer Teaching Observation Checklist (CTOCL) was used to assess method used by each computer course lecturer to train the would-be computer lecturers in Computer Science Department at the two Colleges of Education in Osun State. The result was analysed and presented in Table 6.According to information on Table 4 and 5 , the ratio of available number of computers in the COE to the sample population of the study was 41:11 (approximately 4:1). This implies that, 4 students will be using one computer. However, the ratio of the functional computers to students is 168:19 (approximately 9:1). This translates to nine students on a functional computer.
From Table 1 and 4.3e, the ratio of available number of computers in the Colleges to the population of computer science students was 23:1 (approximately 23:1). This translates to twenty three (23) students to use computer. While the ratio of functional computers in the two Colleges of Education to the population of computer science students in the Colleges is $52: 1$.That is 53 students to use one computer. It can therefore be concluded that the numbers of computers available for the use of the pre-service teachers' practical demonstration in software programming were not adequate.

RQ3: What are the strategies employed by the CSE lecturers for training the pre-service teachers? 
Table 6. Strategies of Teaching Would-be Computer Teachers

\begin{tabular}{|l|l|l|}
\hline Responses & \multicolumn{2}{|c|}{} \\
\hline Methods of Teaching & $\mathrm{N}$ & Percent \\
\hline Lecture Method only & 22 & $33.8 \%$ \\
\hline Lecture Method and Others & 18 & $27.7 \%$ \\
\hline Discussion method & 14 & $21.5 \%$ \\
\hline Demonstration Method & 2 & $3.1 \%$ \\
\hline Project Method & 8 & $12.3 \%$ \\
\hline Computer (Practical) & 1 & $1.5 \%$ \\
\hline Total & 65 & $100.0 \%$ \\
\hline
\end{tabular}

To answer this research question, a Computer Teaching Observation Checklist (CTOCL) was used to assess method used by each computer course lecturer to train the would-be computer lecturers in Computer Science Department at the two Colleges of Education in Osun State. The result was analysed and presented in Table 6.

From Table 6, 33.8\% of Lecture Method only was used by the lecturers to teach computer preservice teachers, while $27.7 \%$ of Lecture Method and other Teaching Methods was used, $21.5 \%$ of Discussion Method, 3.1\% of Demonstration Method, $12.3 \%$ Project Method, and 1.5\% Practical demonstration Method were used. It then implies that the most commonly used teaching method is Lecture Method. It can therefore be concluded that $1.5 \%$ of computer Practical demonstration Method of teaching is not adequate for training the computer pre-service teachers.

RQ4: How proficient are the learners in computer software and hardware utilization?

To answer this research question, Computer Hardware/Software Achievement Test (CHSAT) was administering on the pre-service teachers to determine their proficiency in a computer programming language and computer hardware. The result was analysed using simple percentage. The result is as shown in Table 7 .

Table 7. Proficiency in Computer Software and Hardware Components

\begin{tabular}{|l|l|l|l|l|}
\hline Proficiency & Software Component & Hardware Component & \% of Software Component & \% of Hardware Component \\
\hline Low & 155 & 112 & $92.3 \%$ & $66.7 \%$ \\
\hline Average & 6 & 30 & $3.6 \%$ & $17.9 \%$ \\
\hline Good & 7 & 26 & $4.2 \%$ & $15.5 \%$ \\
\hline
\end{tabular}

From the Table 7, proficiency was rated $0-39.4 \%$ represented low proficiency, 39.5\%-49.4\% represented average proficiency and $49.5 \%$ and above represented good proficiency. Based on these scale the study reveals that $92.3 \%$ of the pre-service computer teachers had low proficiency in software components, $3.6 \%$ had average proficiency in software proficiency and $4.2 \%$ had good proficiency in software components. While $66.7 \%$ had low proficiency in computer hardware components, $17.9 \%$ had average proficiency and $15.5 \%$ had good proficiency in computer hardware component. It can be concluded that the CSE pre-service teachers in Osun State Colleges of Education were not proficient in computer software and hardware component because they had low level of computer software and hardware component proficiency.

\section{Discussion}

The results of this study showed different factors responsible for inadequacy of effective training of pre-service teachers learning how to teach ICT as a subject at Nigerian Colleges of Education. These barriers also have ripple effect on the teaching and learning of ICT literacy in Nigerian secondary schools.

The study shows that $54.5 \%$ of the computer teacher educators in Osun State Colleges of Education were qualified while $18.2 \%$ of them could be qualified if enrolled in any of the tertiary institution for teaching Responses Methods of Teaching N Percent Lecture Method only $2233.8 \%$ Lecture Method and Others 18 27.7\% Discussion method 14 21.5\% Demonstration Method $23.1 \%$ Project Method 8 12.3\% Computer (Practical) 1 $1.5 \%$ Total $65 \quad 100.0 \%$ Proficiency Software Component Hardware Component \% of Software Component $\%$ of Hardware Component Low 155 $11292.3 \%$ 66.7\% Average $6303.6 \% 17.9 \%$ Good 7 $264.2 \% 15.5 \%$ qualification programmes. However, $27.3 \%$ of them were not qualified to lecture. Therefore, only $54.5 \%$ of the CSE academic staff was qualified according to NCCE requirements. This finding was supported by the findings of Nwangwu, Obi and Ogwu [5], and Toscany-Academy [9]. 
In addition, the study showed that there were 5 and 6 computer teacher educators in Osun State College of Education Ilesa and Ila respectively. Based on this finding, staff-student ratio was examined and the result shown 1:60.4 in Ilesa, 1:115 in Ila and while the total overall staff-student ratio for the two COE was 1:90. According to NCCE document, there must be a minimum of eight (8) Computer Science Education academic staff in a College of Education. It further stated that the staffstudents ratio should be $1: 25$. In view of the requirement of NCCE document, this study result implies that the teacher educators were not adequate as such more computer teacher educators will be required to meet the size of computer pre-service teachers from the two Colleges of Education. According to the findings of Goshit [13], the major challenge confronting Nigeria schools and its ICT programme is workforce training. Lack of ICT teachers was also found in Adomi and Kpangban [1].

Furthermore in the study, $43.2 \%$ of the component of computer facilities were functional, $68.2 \%$ of the computers were on local network, while $31.8 \%$ of the available computers had the following components: computers with INTEL PIV 3GHZ (100 FSB) MMX, DVD ROM Drive, Flat Screen Monitor, USB Keyboard and Mouse. While $29.5 \%$ had 120 GBHD and none had 2GB Ram. None of the computers was connected to the Internet, no scanner was found in the laboratories for students and lecturers' use and no teacher educator was presented departmental laptop in the Departments of Computer Science Education of the two Colleges of Education. In view of this finding, the computer facilities in the two Colleges of Education did not met up to the quality expected for use to transmit knowledge. It is inferred that most of the computer systems will be slow to run any object oriented programming software for practice. Even when the software is ran, practical self-efficacy of the learners in software will be low and the learners might not be able to connect to the Internet to get better understandings required. Oyelekan [14] found similar results from a study conducted in the two Colleges of Education in Plateau State. In addition, the findings of Olakulehin [17], Aduwa-Ogiegbaen and Iyamu [18], Yang [19] as well as Yusuf [15] found that in Africa, there is low access to basic ICT equipment, low internet connectivity, low participation in the development of ICT equipment, and even low involvement in software development.

Again, the study revealed that the ratio of available number of ICT facilities in terms of computer component from the two Colleges in relation to the study sample population was 11:41 (approximately 1:4). This implies that, one computer will be shared among a group of 4 students. Likewise, the ratio of functional computers to the respondent was 19:168 (approximately 1: 9). This also translates to a functional computer to a group of nine students. Furthermore, the ratio of available number of computers in the COEs to the population of Computer Science Education students is 23:1. This translates to twenty three (23) students to use a computer. While the ratio of functional computers from the two Colleges of Education to the population of computer science students from the Colleges is 52:1.This implies that 52 pre-service teachers are to use one computer. According to NCCE document stipulation, two students to use one computer if any College is to float a Computer Science Education programme, as a minimum condition. In view of these findings, it is therefore apparent that, the Colleges are far from reaching the ICT facilities requirement for the programme. As such the learners might not have enough time to practice many practical related courses before they graduated. However, Warschauer [21] study found out that the overall ratio of students to instructional computers with Internet access in U.S. public schools as at 2008 was $1: 3$.

The finding also showed that $33.8 \%$ of Lecture Method (traditional method) was used by the lecturers to teach computer pre-service teachers, while $27.7 \%$ shows Lecture Method and other Teaching Methods used, $21.5 \%$ of Discussion Method, $3.1 \%$ of Demonstration Method, $12.3 \%$ Project Method, and $1.5 \%$ Practical demonstration Method was used. In view of these results, it shows that some of the strategies specified in NCCE document were poorly applied, such like practical demonstration method which indicates $1.5 \%$. It can be drawn from the results that $61.5 \%$ of lecture method used by the computer teacher educators was not appropriate to train pre-service teachers on how to teach ICT as a subject. This is because traditional way of teaching is cannot adequately prepare learners to meet the 21 st century challenges. With this, the pre-service teachers' hardware and software programming self-efficacy will be poor as they apply skills acquired to implement ICT curriculum at Junior Secondary Schools. As such, Alade [22] opined that there is an urgent need for a paradigm shift from theoretical teaching and literary application to a practical demonstration application of knowledge necessary for employment and skill development.

Finally, the study showed that $92.3 \%$ of the preservice computer teachers had low proficiency in software components, $3.6 \%$ had average proficiency in software proficiency, $2.4 \%$ had good proficiency in software components and $1.8 \%$ of them had excellent proficiency in computer software component. While $66.7 \%$ had low proficiency in computer hardware components, $17.9 \%$ had average proficiency, $15.5 \%$ had good proficiency in computer hardware components and none had excellent proficiency in computer hardware 
components. Yusuf [15] finding also reported low involvement in software development. Based on this finding, it can be concluded that the CSE pre-service teachers in Osun State Colleges of Education had low level of computer software and hardware component proficiency. This could in turn hinder the effective teaching of ICT literacy in Nigerian secondary schools.

\section{Conclusion and Recommendations}

The study concluded that the CSE pre-service teachers in Osun State Colleges of Education were not proficient in computer software and hardware component because they had low level of computer software and hardware component proficiency. It became apparent that there are factors responsible for the poor performance of the pre-service teachers in the learning of computer science education in Nigeria teacher education. These barriers also could be responsible for the setback being experienced in the teaching of ICT in Nigerian secondary schools. It is therefore recommended that the education stakeholders in Nigerian teachers' education to provide adequate ICT facilities, training opportunities for the teacher educators that will improve the learning of pre-service teachers, as well review the teacher education curriculum to be able to drive the 21 st century education effectively in Nigeria.

\section{Acknowledgements}

The Author would like to thank his senior colleagues in the Institute of Education, Obafemi Awolowo University for their assistance and support in the preparation of this paper.

\section{References}

[1] E.E. Adomi, E. Kpangban, Application of ICTs in Nigerian secondary schools, Library Philosophy and Practice (e-journal), (2010) 345.

[2] O. Adebowale, N. Dare, Teachers' Awareness of Nigeria's Educational Policy on ICT and the use of ICT in Oyo State Secondary Schools, International journal of computing and ICT research, 6 (2012) 84-93.

[3] O.A. Sofowora, The diffusion of information and Communication technology in primary Schools in Nigeria: Utilization and challenges, International Journal of Cyber Society and Education, 5 (2012) 23.

[4] P.O. Jegede, J.A. Owolabi, Computer education in Nigerian secondary schools: Gaps between policy and practice, Meridian: A Middle School Technology Journal, 6 (2003) 1-11.
[5] E.C. Nwangwu, C.A. Obi, E.N. Ogwu, Integration of Information Communication Technology (ICT) in the Curriculum of Federal Unity Schools (FUS) in Nigeria: Implications for Learning, Greener Journal of Educational Research, 4 (2014) 91-98.

[6] O. Adeosun, Quality basic education development in Nigeria: Imperative for use of ICT, Journal of International Cooperation in education, 13 (2010) 193-211.

[7] P.O. Jegede, Assessment of Nigerian teacher educators' ICT Training, Issues in Informing Science and Information Technology, 6 (2009) 415-420.

[8] H. Odogwu, survey of computer education in secondary schools. ASSU-UNILAG, Journal of contemporary Studies, 1 (2000) 24-24.

[9] Toscany-Academy, Computer Education in Nigeria Secondary Schools, Statistical Annex Table, 2012.

[10] N. National Commission for Colleges of Education, Computer Science, NCCE Publishing2012.

[11] G.M. Chao, Impact of Teacher Training on Information Communication Technology Integration in Public Secondary Schools in Mombasa County, Human Resource Management Research, 5 (2015) 77-94.

[12] N. Mndzebele, Teachers readiness in using ICT in the classroom: the case of a developing country, International Journal of Information and Education Technology, 3 (2013) 409

[13] T. Goshit, Nigeria's need for ICT: SP. 259 technology and policy in Africa, Retrieved November, 23 (2006) 2006.

[14] O.S. Oyelekan, An Overview of the Status of Information and Communication Technology (ICT) in the Nigerian Education System, The African Symposium, 2008, pp. 8.

[15] M.O. Yusuf, Information and Communication Technology and Education: Analysing the Nigerian National Policy for Information Technology, International Education Journal, 6 (2005) 316-321.

[16] C. Okwudishu, Awareness and use of information and communication technology (ICT) among village secondary school teachers in Aniocha South Local Government Area of Delta State, Unpublished B. Sc.(LIS) project, (2005).

[17] F.K. Olakulehin, Information and Communication Technologies in Teacher Training and Professional Development in Nigeria, Online Submission, 8 (2007) 133-142.

[18] S.E. Aduwa-Ogiegbaen, E.O.S. Iyamu, Using information and communication technology in secondary schools in Nigeria: Problems and prospects, Journal of Educational Technology \& Society, 8 (2005) 104-112.

[19] Y. Yang, Examining university students' and academics' understandings of ICTs in higher education, 
Changing Climates: Education for Sustainable Futures, 2009, pp. 1-13.

[20] L. Arenyeka, Forgotten aspects of education Vanguard News, (2013).

[21] M. Warschauer, Invited commentary: New tools for teaching writing, Language learning \& technology, 14 (2010) 3-8.

[22] I.A. Alade, Trends and issues on curriculum review in Nigeria and the need for paradigm shift in educational practice, Journal of Emerging Trends in Educational Research and Policy Studies, 2 (2011) 325-333.

[23] E.F. Bamidele, Effectiveness of a Computer Assisted Instruction in the Teaching of Secondary School Practical Chemistry., (2002).

[24] C.P. Newhouse, The impact of ICT on learning and teaching, Perth: Special Educational Service, (2002).

[25] J. Cradler, E. Bridgforth, Recent research on the effects of technology on teaching and learning. [online]. WestEd, Retrieved 25/10/2002, 2002, from the World Wide Web: www. wested. org/techpolicy/research. html, 2002.

[26] A. Tella, A. Tella, O.M. Toyobo, L.O. Adika, A.A. Adeyinka, An Assessment of Secondary School Teachers Uses of ICT's: Implications for Further Development of ICT's Use in Nigerian Secondary Schools, Online Submission, 6 (2007). 